\title{
Teresa Wright, Party and State in Post-Mao China,
} Malden, Cambridge, Polity Press, 2015, 200 pp.

\section{Emilie Tran}

\section{OpenEdition}

\section{Journals}

Electronic version

URL: http://journals.openedition.org/chinaperspectives/7002

DOI: 10.4000/chinaperspectives.7002

ISSN: 1996-4617

\section{Publisher}

Centre d'étude français sur la Chine contemporaine

\section{Printed version}

Date of publication: 1 June 2016

Number of pages: 76-77

ISSN: 2070-3449

Electronic reference

Emilie Tran, «Teresa Wright, Party and State in Post-Mao China, », China Perspectives [Online], 2016/2 I 2016, Online since 01 June 2016, connection on 23 September 2020. URL : http://

journals.openedition.org/chinaperspectives/7002 ; DOI : https://doi.org/10.4000/chinaperspectives. 7002

(c) All rights reserved 
a scholar-turned-civil servant insists on the achievements of the past 15 years and somehow blames the previous colonial administration for some of the most important present difficulties - while never failing to make multiple references to the "harmonious" nature of society; a former number two in the colonial administration turned head of an educational institute praises the Portuguese heritage and how "accommodation" provided the perfect conditions for a successful transition, but warns nonetheless that fast-paced development constitutes a threat to Macao's unique identity whatever that is; and last but not least, Ming K. Chan's own chapter manages to reconcile these two by pondering Macao's history in the long run and what he characterises as current issues of "over-development." Clearly, a diverse and contrasted take on what Macao is today.

\section{IÉric Sautedé is an associate researcher with the CEFC} (esautede@gmail.com).

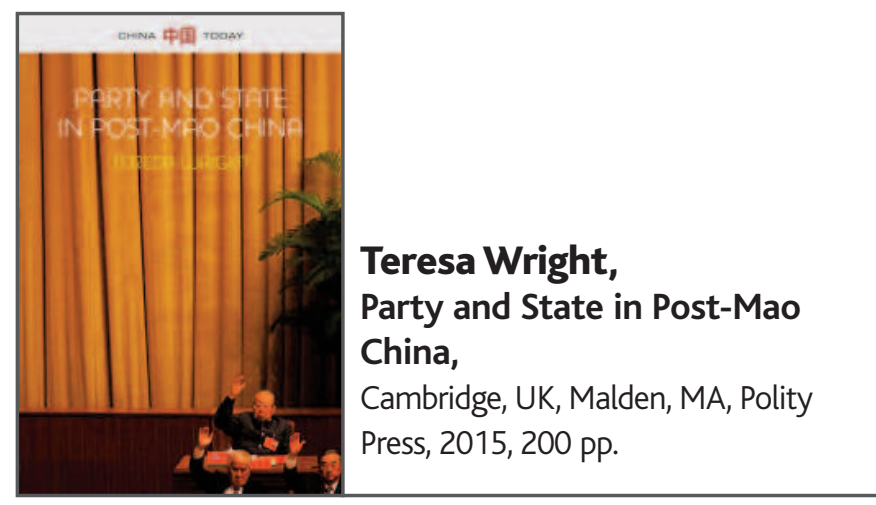

\section{ÉMILIE TRAN}

$\mathrm{P}$ arty and State in Post-Mao China is one of 15 or so titles thus far in the "China Today" series of Polity Press, an academic publisher whose stated aim is to reach out to the general readership by inviting leading China scholars around the world to write concise introductory books on key aspects of China's struggles and accomplishments in becoming a leading world power. In this volume, the author, Teresa Wright, professor and chair of the Department of Political Science at California State University, Long Beach, offers her perspectives to decipher the main China paradox: despite the dramatic economic and social changes in the post-Mao period, China's polity has remained essentially and steadily authoritarian - "Opposition parties are not permitted, the public has no right to vote for top political leaders, the media is censored, and political dissent is repressed" (pp. 3-4) - thus challenging the assumption that authoritarian regimes are by nature unstable, since "at the same time, Chinese citizens have evidenced remarkable toleration of - and even support for - China's CCP-controlled political system" (p. 4). In Chapter 1, "Sources of Stable Governance in China,"Wright enunciates the two questions her book aims to answer: "(1) how well does China's Party-state satisfy the basic functions of government?" and "(2) how has the Chinese government's democratic and authoritarian features influenced its ability to fulfil these functions?" (p. 12).

The book is then divided into two main parts. Part I examines the nature of the Chinese Party-state, contrasting the features that have endured over time (Chapter 2) with the evolving traits (Chapter 3): whereas Chapter 2, "Party and State, or Party-State?", offers an overview of the principal entities of China's political system, from the highest central level to the lowest local level, showing that although the Party and the state are nominally two separate bodies, the Party has been controlling the state, Chapter 3, "Who Serves the Party-State?", reviews the demographic composition, selection, and ascension process of the members and leadership of both the Party and the state, arguing that in the post-Mao era they have become more meritocratic, regularised, and somewhat more democratic. However, far from having been conducive to the formation of a multi-party liberal democracy, these latter post-Mao trends have rather been a way to strengthen and stabilize [italicised in the text] the CCP's rule, creating a polity that "differs substantially from both the Maoist system and liberal democratic systems in the West, and may remain more or less as is for the foreseeable future" (p. 75).

Having depicted the essence of the post-Mao political system, the second part, comprised of chapters 4,5, and 6, reviews the extent to which the system has actually fulfilled its functions in "Maintaining Public Relations" (Chapter 4), "Managing the Economy" (Chapter 5), and "Providing Coods and Services" (Chapter 6). The author argues that the stability and longevity of the ruling Party-state is conditioned by its successes or failures in those three areas. Chapter 4 assesses how well the Party-state satisfies key demographic groups, namely private businesspeople, college students and graduates, rank and file workers, farmers, ethnic minorities, and environmental protesters, and concludes that "although the Chinese political system remains authoritarian in many ways, in the post-Mao period it has engaged in an adequate - and generally improving - job of responding to public grievances and satisfying the needs of important demographic groups" (p. 110). Chapter 5 assesses economic policy in the post-Mao era, reviewing rural, urban, and international economic policies and results, and demonstrates that "when it comes to managing the economy and promoting economic growth, the Party-state's record is much more impressive, [enabling] China's economy to not only grow at an astounding rate, but also to avoid severe crises" (p. 113), and this thanks to "the attitudes and quality of the political leadership [that] are key in determining the system's success or failure at managing the economy" (p. 144). The third essential requirement of a stable governing regime is how well the latter facilitates access to necessary goods and services, and alleviates poverty, through the provision of pensions, housing/land, healthcare, education, infrastructure, and a healthy natural environment. Here the record is rather mixed, with impressive achievements in some areas and severe regression in others, aggravated by an uneven distribution of goods and services across the populace and across the country. Nevertheless, Wright notes that "with regards to some goods and services (such as infrastructure), China's lack of elections may allow the regime to act more quickly and decisively than is the case in many liberal democracies" (p. 179).

The concluding chapter, entitled "Stable Authoritarianism?", maintains that ideology had been replaced by pragmatism, defined as a "hybrid mixture of authoritarian, democratic, state-interventionist, and capitalist features" (p. 180) that have enabled political leaders who are "competent, pragmatic and open to public input" (p. 195) to enact and effectively implement policies that "adequately fulfil the basic functions of a government" (p. 180), as demonstrated in the second part of the book. However, as Wright briefly presents the new developments under $X i$ Jinping, she warns that his efforts to control public expression are jeopardising the modus operandi of state-society relations in the late post-Mao period that used to savvily articulate public grievances and the Party-state's capacity to respond to those more or less satisfactorily. 
Party and State in Post-Mao China is definitively an accessible must-read primary reference for students not only in China studies, but also in political science, and especially those with a keen interest in the workings of an authoritarian regime, exemplified by China's contemporary political system. Page after page, from 1 to 195 , Wright didactically reckons the whys and wherefores of the unforeseen longevity of the Chinese Party-state, although in so doing, the author could have avoided recounting the same argument with almost exactly the same wording: "a complementary set of work clothes and shoes each year" (p. 98) and "a free set of work clothes and shoes each year" (p. 151); another instance: "they [manual labourers] have had a safety net of land rights back in their home villages in the event that things go awry in the city" (p. 100), and "If things do not work out in the city, these migrants know that they can return to their home village where their family will have land and a home, and their subsistence will be assured" (p. 120). Whereas this is a slight issue that can be easily addressed in the second edition of the book - along with a typo on page 134: "though" instead of "through" - the book has a shortcoming that derives from the very phrasing of the first inquiry the author set out to answer. Indeed, by asking, "How well does China Party-state satisfy the basic functions of government?" (p. 12), the argument is directed to emphasise and outweigh the factors of stability and strength over the elements of instability and weakness: other contingent causes and inherent characteristics of an authoritarian state would have deserved a more thorough review. Indeed, the stability of the regime cannot be explained merely by the fact that the Chinese Party-state has somewhat suitably performed the basic functions of a government; its longevity also relies on how effectively the regime has more or less systematically eradicated all forms of organised dissent and the voicing of politically incorrect positions, thus nipping in the bud any attempt at building a diverse and vivid Chinese civil society, the prerequisite to regime change. Possibly the concise format of the "China Today" book series has not allowed space to delve into those considerations, and one might wish the second edition of Party and State in Post-Mao China to include those arguments, or even better, to have another book in the series that would complement Wright's by looking specifically at the totalitarianturned-authoritarian and currently totalitarian-leaning attributes and trends of China's polity to explain what Andrew Nathan has labelled as "authoritarian resilience." (1)

IÉmilie Tran is associate professor and coordinator for the Department of Public Administration and International Relations at the University of Saint Joseph, Macau, as well as an associate researcher with CEFC (emilie.tran@usj.edu.mo).

1. Andrew Nathan, "China's Changing of the Guard: Authoritarian Resilience," Journal of Democracy, Vol. 14, No. 1, January 2003, pp. 6-17.

\section{Books received}

Jean-Pierre Cabestan, La politique internationale de la Chine. Entre intégration et volonté de puissance (China's international policy: Between integration and will to power), $2^{\text {nd }}$ edition, updated and expanded, Paris, Presses de Sciences Po, 2015, 640 pp.

Cai Fang, China's Economic Growth Prospects: From Demographic Dividend to Reform Dividend, Cheltenham, UK, Northampton, MA, Edward Elgar Publishing, 2016, 256 pp.

\section{Elisabeth L. Engebretsen and William F.} Schroeder (eds), Queer/Tongzhi China: New Perspectives on Research, Activism and Media Cultures, Copenhagen, NIAS Press, 2015, 320 pp.

\section{Manuelle Franck and Thierry Sanjuan (eds),} Territoires de l'urbain en Asie. Une nouvelle modernité ? (Urban territories in Asia: A new modernity?), Paris, CNRS Éditions, 2015, 404 pp.

\section{Karsten Giese and Laurence Marfaing (eds),} Entrepreneurs africains et chinois. Les impacts sociaux d'une rencontre particulière (African and Chinese entrepreneurs: Social impacts of a particular encounter), Paris, Karthala, 2016, 384 pp.

\section{François Gipouloux (ed.), China's Urban Cen-} tury: Governance, Environment and Socio-Economic Imperatives, Cheltenham, UK, Northampton, MA, Edward Elgar Publishing, 2015, 287 pp.

\section{David S.G. Goodman (ed.), Handbook of the} Politics of China, Cheltenham, UK, Northampton, MA, Edward Elgar Publishing, 2015, 576 pp.

Yingjie Guo (ed.), Handbook on Class and Social Stratification in China, Cheltenham, UK, Northampton, MA, Edward Elgar Publishing, 2016, 448 pp.

\section{Guobin Yang (ed.), China's Contested Internet,} Copenhagen, NIAS Press, 2015, 312 pp.

Hong Liu, The Chinese Strategic Mind, Cheltenham, UK, Northampton, MA, Edward Elgar Publishing, 2015, 224 pp.

Orna Naftali, Children in China, Cambridge, UK, Malden, MA, Polity Press, 2016, 192 pp.

Judith Shapiro, China's Environmental Challenges, $2^{\text {nd }}$ edition, Cambridge, UK, Malden, MA, Polity Press, 2016, $256 \mathrm{pp}$. 